Received 23.10.2017

Reviewed 12.11.2017

Accepted 21.11.2017

A - study design

B - data collection

C - statistical analysis

D - data interpretation

$\mathbf{E}$ - manuscript preparation

F - literature search

\title{
The change of quantity and quality outflow of water in Ochożanka River basin
}

\author{
Antoni GRZYWNA ${ }^{\text {ABCDEF } 凶}$
}

University of Life Sciences in Lublin, Faculty of Production Engineering, Department of Environmental Engineering and Geodesy, ul. Leszczyńskiego 7, 20-069 Lublin, Poland; e-mail: antoni.grzywna@up.lublin.pl

For citation: Grzywna A. 2017. The change of quantity and quality outflow of water in Ochożanka River basin. Journal of Water and Land Development. No. 35 p. 57-62. DOI: 10.1515/jwld-2017-0068.

\begin{abstract}
The aim of this research work is to evaluate changes in the quantities of water and chemical parameters of outflow water from the forest catchment. Research was carried over a hydrological five-year period in the Ochożanka River basin (Western Polesie). The structure of the catchment area of $33.1 \mathrm{~km}^{2}$ is dominated by forestland constituting $81 \%$ of the area. During this period the precipitation amounted to $627 \mathrm{~mm}$, which was $100 \mathrm{~mm}$ higher than the multi-year average. Precipitation of the summer half-year was almost three times higher than in the winter half-year. Data analysis shows that the average unit outflow from the catchment unit was 3.0 $\mathrm{dm}^{3} \cdot \mathrm{s}^{-1} \cdot \mathrm{km}^{-2}$. Outflow in the winter half-year was $52 \%$ higher than in the summer half-year. The waters of the river are used, they are usually characterized by good chemical status. In case $30 \%$ samples concentration of Kjeldahl nitrogen $\left(>2 \mathrm{mg} \mathrm{N} \cdot \mathrm{dm}^{-3}\right)$, total phosphorus $\left(>0.4 \mathrm{mg} \mathrm{P} \cdot \mathrm{dm}^{-3}\right)$ exceed the limit values for second class quality water. Indicators of oxygen conditions reach medium and high values. In spring, it happens that the limits are exceeded for second class water quality. These values are respectively COD $>20 \mathrm{mg} \mathrm{O}_{2} \cdot \mathrm{dm}^{-3}$ and oxygen $<5 \mathrm{mg} \mathrm{O}_{2} \cdot \mathrm{dm}^{-3}$. An important issue related to the value parameters is the seasonal variability of their concentration in water outflow from the catchment. The maximum value chemical parameters are recorded in March, when the occurred largest outflows water.
\end{abstract}

Key words: forest catchment, precipitation, quality class, water outflow

\section{INTRODUCTION}

The quantity and quality of water resources determine the status, health and even the existence of forestland. In turn, forests and wetlands play an extremely important role in shaping the circulation of water in the catchment area and in improving its quality. The impact of the forest on quantitative and qualitative hydrological characteristics is more explicit in smaller catchments. The results of hydrological studies carried out in catchment areas of different size and with different land cover may point to different relationships [CALDER et al. 2007; PIERZGALSKI 2008; VAN DIJK, KEENAN 2007].

A great role is attributed to forests in mitigating extreme hydrological phenomena, namely in protect- ing against floods and reducing the effects of droughts. It is generally acknowledged that forest reduces and delays overflows and increases baseflows. The statistically significant relationship between vegetation cover and the outflow of water is confirmed by the results of hydrological studies carried out in watercourse catchments in the Sudeten which were deforested in the 1980s. Removal of tree stands almost immediately increased outflows by up to $35 \%$. Forestation influenced changes to water circulation again [PIERZGALSKI et al. 2007; ŻELAZNY et al. 2017]. Research shows that at a very early stage of reconstruction of the forest in the Ciekon creek catchment area (deforested in $40 \%$ as a result of an ecological disaster) differences in the outflow from the catchment increased to $200 \%$. As the stands de- 
velop, this relationship becomes more stable and resembles the status before deforestation.

Research on the impact of forests on mitigating droughts are more ambiguous in references. In their study in the Republic of South Africa, ScOTT and SMITH [1997] found that the forest increased water deficits in dry periods. In contrast, studies carried out in England have shown that the opposite is true. Another issue is the threat of environmental pollution [JARVIE et al. 2010]. The load of nutrients from a forest catchment is much smaller than from an agricultural catchment [KOC et al. 2008].

The aim of this paper is to evaluate the changes in the quantity and chemical parameters of outflow water from the forest catchment. The research was carried out for five hydrological years in Western Polesie in the Lowering Sosnowica mesoregion.

\section{MATERIAL AND METHODS}

The Ochożanka River catchment is located in the central part of the Parczew Forests $\left(51^{\circ} 32^{\prime} 30^{\prime}\right.$ N, $\left.23^{\circ} 00^{\prime} 30^{\prime \prime} \mathrm{E}\right)$. The land surface is poorly diversified, with low hills being the only distinguishing feature. The grassland drained in the years 1930-1932 was 458 ha with a total catchment area amounting to 33.1 $\mathrm{km}^{2}$. The average decline is $1.5 \%$ for the analyzed basin. The structure of land use is dominated by forestland accounting for $81 \%$ of the area. Forest habitats are arranged in zones according to the relief. Alder woods continue along the bottom of the valley. The slopes are overgrown with fresh mixed forests and fresh mixed coniferous forests. The bottom of the valley lacking wooded areas has an elongated shape with regularly outlined limits of agricultural and forestland. Its length is $10 \mathrm{~km}$ and the width is about $200 \mathrm{~m}$. The bottom of the valley is covered with one cut seminatural meadows with a plantation of blueberries situated in the middle part.

In the part of the valley lacking wooded areas moderately transformed soils and mud and mineral soils are predominant. The drainage structure has $80 \%$ peat cover. In the immediate vicinity of the bottom of the valley, there are rust-coloured and brown sand soils. The paper is based on the results of field studies carried out in hydrological years from 2009/2010 to 2013/2014 (adjustable outflow).

Research and observations included:

- daily recording of the levels of surface waters in the section closing the catchment;

- daily measurements of precipitation at the meteorological station in Sosnowica;

- monthly water flow measurements in the section closing the catchment;

- monthly random water sampling in the section closing the catchment.

The characteristics of forest soil were described based on the soil and habitat statement of Parczew Forestry. The variability of the water outflow was assessed on the basis of the average unit outflow from the catchment. The total outflow of water was calculated based on the value of the unit outflow and the area of the catchment. Chemical analyses of water were performed during field studies and at the laboratory of the University of Life Sciences in Lublin. The concentration of total phosphorus, phosphates, sulphates, ammonium and nitrate nitrogen and total nitrogen in water samples was determined by means of the spectrophotometric method [GRZYWNA et al. 2015]. BOD, COD and oxygen measured by multiparameters sensor. At first stage, the flow of water in the section closing the catchment was used as the basis for calculating the unit and total outflow. At the second stage, the characteristic chemical parameters were determined and river water quality was evaluated [Rozporządzenie... 2016].

Elaboration of the results comprised determining the minimum and maximum values of individual indices and computing the arithmetic means. Statistical inference about the significance of differences of indices values between the research periods was conducted by means of non-parametric Mann-Whitney U test on the significance level $\alpha=0.05$. The test was chosen because of the lack of distribution normality for a majority of analyzed indices, according to the results of Shapiro-Wilk test and the lack of the equality of variance determined by the Fisher-Snedecor test.

\section{RESULTS}

The Ochożanka River catchment is located in Western Polesie, which is a region characterized by the lowest atmospheric precipitation in Poland. Between 1985 and 2014, the average annual rainfall amounted to $527 \mathrm{~mm}$, of which $169 \mathrm{~mm} \mathrm{(32 \% )} \mathrm{was}$ recorded in the winter half-year (XI-IV) and $358 \mathrm{~mm}$ $(68 \%)$ in the summer half-year $(\mathrm{V}-\mathrm{X})$. At the same time, in this area there are large water losses due to evaporation. Evapotranspiration calculated for Western Polesie in the years 2010-14 was $516 \mathrm{~mm}$ [GRZYWNA et al. 2016]. The hydrological period of 5 years was characterized by high variability of precipitation (Tab. 1). The analysis of annual precipitation suggests that in the analyzed period were wet [KACZOROWSKA 1962]. During this period, the precipitation amounted to $627 \mathrm{~mm}$ and was $100 \mathrm{~mm}$ higher than the multi-year average. The highest rainfall was recorded in the hydrological year 2013/2014, when it amounted to $683 \mathrm{~mm}$, which was 30\% higher than the multi-year average. The lowest rainfall was recorded in 2011/2012, when it amounted to $521 \mathrm{~mm}$ and was close to the multi-year average. In the winter hydrological half-year the highest precipitation was recorded in 2013/2014 - $193 \mathrm{~mm}$, while the lowest in 2009/2010 - $134 \mathrm{~mm}$. Precipitation was considerably more varied in the summer half. It ranged from 373 $\mathrm{mm}$ in $2011 / 2012$ to $541 \mathrm{~mm}$ in $2009 / 2010$ (51\% higher than the multi-year average). 
Table 1. Periodic precipitation totals (mm)

\begin{tabular}{|c|c|c|c|c|}
\hline Year & XI-IV & V-X & XI-X & Classification \\
\hline $2009 / 2010$ & 134 & 541 & 675 & very wet \\
\hline $2010 / 2011$ & 167 & 486 & 653 & wet \\
\hline $2011 / 2012$ & 148 & 373 & 521 & normal \\
\hline $2012 / 2013$ & 189 & 416 & 605 & wet \\
\hline $2013 / 2014$ & 193 & 490 & 683 & very wet \\
\hline Average & 166 & 461 & 627 & wet \\
\hline $1985-2014$ & 169 & 358 & 527 & - \\
\hline
\end{tabular}

Source: own study.

Data analysis shows that in the section closing the catchment area, the average annual unit outflow during the five hydrological years analysed was 3.0 $\mathrm{dm}^{3} \cdot \mathrm{s}^{-1} \cdot \mathrm{km}^{-2}$ (Tab. 2). In respective years this changed from $2.35 \mathrm{dm}^{3} \cdot \mathrm{s}^{-1} \cdot \mathrm{km}^{-2}$ in $2011 / 2012$ to $3.56 \mathrm{dm}^{3} \cdot \mathrm{s}^{-}$ ${ }^{1} \cdot \mathrm{km}^{-2}$ in $2013 / 2014$. The unit outflow was most regular in the summer half-year and ranged from 1.64 $\mathrm{dm}^{3} \cdot \mathrm{s}^{-1} \cdot \mathrm{km}^{-2}$ in $2011 / 2012$ to $2.84 \mathrm{dm}^{3} \cdot \mathrm{s}^{-1} \cdot \mathrm{km}^{-2}$ in $2009 / 2010$. The unit outflow was considerably more variable in the winter half-year, when it ranged from $2.09 \mathrm{dm}^{3} \cdot \mathrm{s}^{-1} \cdot \mathrm{km}^{-2}$ in $2009 / 2010$ to 4.57 $\mathrm{dm}^{3} \cdot \mathrm{s}^{-1} \cdot \mathrm{km}^{-2}$ in $2013 / 2014$. The average unit outflow in the winter half-year was $52 \%$ higher than in the summer half-year. The average total outflow of water from the forest catchment area in the analysed period amounted to 3.13 million $\mathrm{m}^{3}$, of which $60 \%$ was in the winter half-year. The annual total outflow of water ranged from 2.45 to 3.72 million $\mathrm{m}^{3}$.

Table 2. Unit and total outflows of water

\begin{tabular}{|c|c|c|c|c|c|c|}
\hline \multirow{2}{*}{ Year } & \multicolumn{2}{|c|}{ Unit outflow, $\mathrm{dm}^{3} \cdot \mathrm{s}^{-1} \cdot \mathrm{km}^{-2}$} & \multicolumn{3}{|c|}{ Total outflow, $\mathrm{mln} \mathrm{m}^{3}$} \\
\cline { 2 - 7 } & XI-IV & V-X & XI-X & XI-IV & V-X & XI-X \\
\hline $2009 / 2010$ & 2.09 & 2.84 & 2.47 & 1.09 & 1.48 & 2.58 \\
\hline $2010 / 2011$ & 3.81 & 2.72 & 3.26 & 1.99 & 1.42 & 3.41 \\
\hline $2011 / 2012$ & 3.05 & 1.64 & 2.35 & 1.59 & 0.86 & 2.45 \\
\hline $2012 / 2013$ & 4.56 & 2.14 & 3.35 & 2.38 & 1.12 & 3.49 \\
\hline $2013 / 2014$ & 4.57 & 2.55 & 3.56 & 2.39 & 1.33 & 3.72 \\
\hline Average & 3.62 & 2.38 & 3.00 & 1.89 & 1.24 & 3.13 \\
\hline
\end{tabular}

Source: own study.

The waters of the Ochożanka River are used, they are usually characterized by good chemical status in terms of nutrients. Only in the spring period did Kjeldahl nitrogen and phosphates exceed the permissible limits for class II (Tab. 3). The analysis shows that the concentrations of sulphates, total nitrogen and ammonia nitrogen are low. Based on the concentrations of these nutrients, all water samples were classified in class I of water quality [Rozporządzenie... 2016]. For total nitrogen, the highest values were recorded in the spring months and the lowest in the autumn months. Ammonium nitrogen concentrations were characterized by seasonal variations, the highest occurring in winter half-year, and the lowest in summer half-year. Low concentrations of ammonium nitrogen in summer result from the nitrification process and its uptake by plants. The concentrations of nitrate nitrogen in the samples were low. The highest values of total nitrogen were observed at the maximum flow
Table 3. Chemical parameters of water in the section closing the catchment

\begin{tabular}{|c|c|c|c|}
\hline \multirow{3}{*}{$\begin{array}{c}\text { Parame- } \\
\text { ter }\end{array}$} & \multicolumn{3}{|c|}{ Concentration, $\mathrm{mg} \cdot \mathrm{dm}^{-3}$} \\
\hline & XI-IV & $\mathrm{V}-\mathrm{X}$ & $\mathrm{XI}-\mathrm{X}$ \\
\hline & \multicolumn{3}{|c|}{ mean $(\min -\max )$ value } \\
\hline$P_{\text {og. }}$ & $0.23(0.06-0.39)$ & $0.45(0.25-0.69)$ & $0.34(0.06-0.69)$ \\
\hline $\mathrm{PO}_{4}$ & $0.34(0.10-0.49)$ & $0.51(0.26-0.80)$ & $0.42(0.10-0.80)$ \\
\hline $\mathrm{N}_{\text {og. }}$ & $3.8(2.1-5.3)$ & $2.5(1.2-3.7)$ & $3.2(1.2-5.3)$ \\
\hline $\mathrm{N}-\mathrm{NO}_{3}$ & $1.5(0.9-2.3)$ & $1.0(0.6-1.5)$ & $1.25(0.6-2.3)$ \\
\hline $\mathrm{N}-\mathrm{NH}_{4}$ & $0.45(0.29-0.61)$ & $0.25(0.14-0.37)$ & $0.35(0.14-0.61)$ \\
\hline $\mathrm{N}_{\text {Kjeld. }}$ & $2.0(1.0-3.0)$ & $1.2(0.5-2.0)$ & $1.6(0.5-3.0)$ \\
\hline $\mathrm{SO}_{4}$ & $36(19-80)$ & $19(7-44)$ & $27(7-80)$ \\
\hline BOD & $4.0(2.2-4.4)$ & $2.2(1.5-3.0)$ & $3.1(1.5-4.4)$ \\
\hline COD & $25(19-31)$ & $15(9-20)$ & $19.5(9-31)$ \\
\hline Oxygen & $7.5(6-10)$ & $6.0(4-9)$ & $6.7(4-10)$ \\
\hline
\end{tabular}

Source: own study.

in spring, and the lowest during the full summer period (Fig. 1). High concentrations in spring were related to the leaching of nutrients from organic matter. The decrease in nitrate nitrogen concentrations during summer is due to its use by water vegetation in the river. A different situation was observed for Kjeldahl nitrogen in the winter period: its concentrations in about $35 \%$ of the water samples were higher than the limit value for water quality class II $-2 \mathrm{mg} \cdot \mathrm{dm}^{-3}$. High concentrations of Kjeldahl nitrogen are due to the mineralization of the organic mass of peat bogs in the bottom river valley.
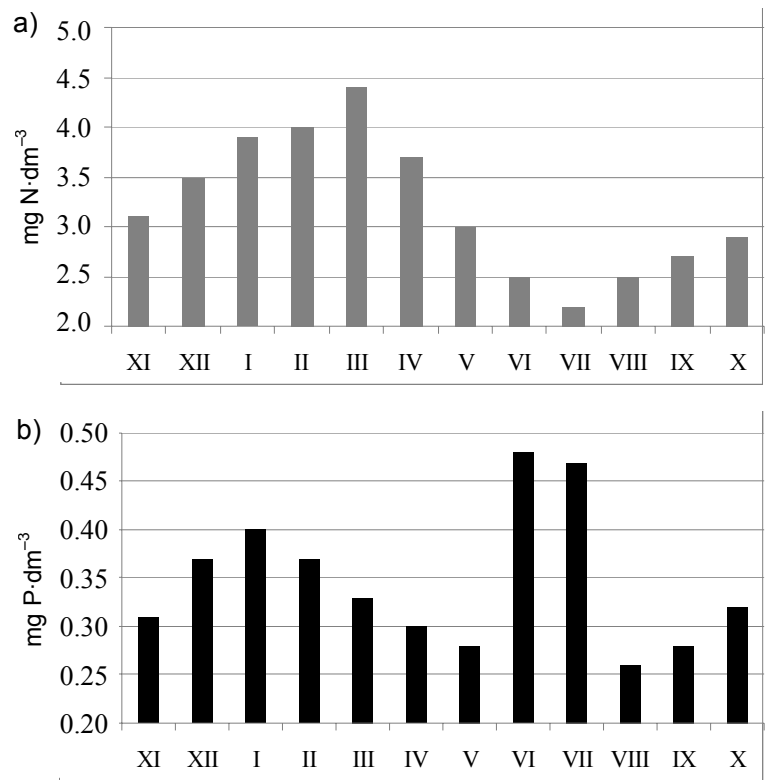

Fig. 1. Average concentrations of a) the total nitrate, b) phosphorus for analysed period; source: own study

Studies show that in the summer period, the phosphorus concentration in samples was higher than the limit value for water quality class II, i.e. 0.4 $\mathrm{mg} \cdot \mathrm{dm}^{-3}$ [Rozporządzenie... 2016]. Similarly, in the case of phosphates during the spring thaw, the limit value for water quality class II were exceeded (Tab. 3). High concentrations of phosphates and phosphorus are due to the use of fungicides on the blueberry plan- 
tation. In the January, June and July (Fig. 1), the limit value of good chemical status was exceeded in $25 \%$.

Concentrations show very high and repetitive seasonal variability. Periods of the increased nitrogen outflow can be identified for the test site during the spring thaw, covering the months from January to April (Fig. 1). In the case of the Ochożanka River catchment area, the daily loads did not exceed $0.5 \mathrm{~kg}$ $\mathrm{N} \cdot \mathrm{d}^{-1} \cdot \mathrm{ha}^{-1}$. The mean total nitrogen discharged from the Ochożanka River catchment area in the multi-year analysis were $3.2 \mathrm{mg} \mathrm{N} \cdot \mathrm{dm}^{-3}$, including ammonium nitrogen $0.37 \mathrm{mg} \mathrm{N}-\mathrm{NH}_{4} \cdot \mathrm{dm}^{-3}$, nitrate nitrogen 1.56 $\mathrm{mg} \mathrm{N}-\mathrm{NO}_{3} \cdot \mathrm{dm}^{-3}$ and organic nitrogen $1.3 \mathrm{mg} \mathrm{N} \cdot \mathrm{dm}^{-3}$. It was observed that the total nitrogen and its forms were $50 \%$ higher in winter than in summer (Tab. 3). In respective months, the loads of nitrogen compounds were characterized by high variability. Calculations have shown that the unit load of total phosphorus leached from the catchment area was 20 times lower than that of total nitrogen. On average it was $0.34 \mathrm{mg} \mathrm{P} \cdot \mathrm{dm}^{-3}$ and it ranged from 0.1 to 0.8 $\mathrm{mg} \mathrm{P} \cdot \mathrm{dm}^{-3}$. All the analyzed nutrients show significant statistical differences on respective test dates.

The analyzed water samples were characterized by a very low sulfate concentration. Their maximum concentration did not exceed $80 \mathrm{mg} \mathrm{SO}_{4} \mathrm{dm}^{-3}$.

Indicators of oxygen conditions reach medium and high values. In spring, it happens that the limits are exceeded for second class water quality. These values are respectively $\mathrm{COD}>20 \mathrm{mg} \mathrm{O} \cdot \mathrm{dm}^{-3}$ and oxygen $<5 \mathrm{mg} \mathrm{O}_{2} \cdot \mathrm{dm}^{-3}$. In the case of BOD $70 \%$ of the samples are classified as water first class quality and the remaining $30 \%$ second class. In the case of oxygen, $10 \%$ of samples do not meet the criterion of good chemical status. The worst situation is with COD, where $30 \%$ of samples do not meet the requirements [Rozporządzenie... 2016].

\section{DISCUSSION}

Both precipitation and unit outflow from the catchment area are highly variable. In the five-year period the average precipitation was $100 \mathrm{~mm}$ higher than the multi-year average. In addition, precipitation in the summer half-year was almost 3 times higher than in the winter half-year. The situation was different in the case of outflow, which in the winter halfyear was 38\% higher than in the summer half-year.

An important issue related to the outflow of nitrogen compounds is the seasonal variability of their concentration in water flowing out of agricultural and forest catchments. The maximum concentrations of nitrates are observed at the turn of February and March, i.e. before the start of agrotechnical works, during the period of the largest outflows, which promotes the removal of nitrates from these catchments [PULIKOWSKI et al. 2011]. Studies in the United Kingdom confirm that the maximum nitrate concentrations occur in early spring [JARVIE et al. 2010; WHEATER, EVANS 2009].
The resulting values are supported by reference literature; very similar values of nitrogen load carried away by the river from the catchment were obtained in analogous meteorological conditions [KoC et al. 2008; SZYMCZYK 2010]. The total nitrogen of the drainage Ochożanka River catchment were significantly lower in comparison with the drainage Miękinia River catchment $\left(5.3 \mathrm{mg} \mathrm{N} \cdot \mathrm{dm}^{-3}\right)$. The results clearly point to high seasonality of nitrogen outflows from the catchment area used for forestry purposes. In lowlands the main threat occurs in early spring. This is due to thawing soil and no uptake by plants. In the case of total phosphorus loads, their variability in hydrological half-years was lower. The calculated total phosphorus loads were higher than those from the Miękinia River catchment $\left(0.22 \mathrm{mg} \mathrm{P} \cdot \mathrm{dm}^{-3}\right)$ and lower compared to the Samotwór catchment (0.37 $\mathrm{mg} \cdot \mathrm{dm}^{-3}$ ) [POKŁADEK, NYC 2007].

In agricultural and forest catchments, solutions travel fast in landscape forms such as grooves, ditches, ruts, linear erosion forms, and underground tunnels constructed by soil animals [HAAG, KAUPENJOHANN 2001; WEILER, MCDONNELL 2007]. The results are similar to the results of research conducted in the central part of the Greater Poland - Kuyavia Lowland. They referred to the evaluation of loads of nutrients leached from the Mała Wełna River catchment. They showed that in the winter half-year the charge of nitrate nitrogen accounted for $83 \%$ of the annual load [KANCLERZ 2011].

The studies revealed a significant impact of the use of the catchment area on the outflow dynamics. An outflow of water from an agricultural catchment in the winter half-year is $150 \%$ higher than in the summer half-year [KORNAŚ, GRZEŚKOWIAK 2011; PULIKOWSKI et al. 2011]. In the studied forest catchment it is only $38 \%$ higher. No significant differences were identified for the average annual outflow. The average annual unit outflow is $20 \%$ lower at the average typical of Western Polesie, that is, $3.8 \mathrm{dm}^{3} \cdot \mathrm{s}^{-1} \cdot \mathrm{km}^{-2}$ [MICHALCZYK, WILGAT 1998]. In addition, no significant impact of the use of the catchment on the load of discharged nutrients was found. The loads of nutrients carried away were only slightly lower than in agricultural catchments. This can be a result of the intensive growing of blueberries at the bottom of the valley.

\section{CONCLUSIONS}

1. The average unit outflow from the catchment was $3.0 \mathrm{dm}^{3} \cdot \mathrm{s}^{-1} \cdot \mathrm{km}^{-2}$. In the winter half-year it was $52 \%$ higher than in the summer half-year.

2. Surface waters were normally characterized by good chemical status in terms of parameters. In case $30 \%$ samples concentration of Kjeldahl nitrogen, total phosphorus, phosphate, oxygen and COD exceed the limit values for quality class II.

3. Chemical parameters show very high and repetitive seasonal variability. Periods of the increased nutrient concentration can be identified for the test site during the spring thaw, in March. 


\section{Acknowledgement}

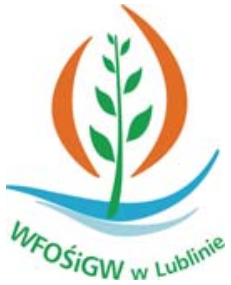

Dofinansowano ze środków

Wojewódzkiego Funduszu

Ochrony Środowiska

i Gospodarki Wodnej w Lublinie

Cofinanced by Voivodeship Fund

for Environmental Protection

and Water Management in Lublin

\section{REFERENCES}

Calder I., Hofer T., Vermont S., Warren P. 2007. Towards a new understanding of forest and water. Unasylva. Vol. 229 (58) p. 1-10.

GrZYwnA A., CZARNECKI Z., WĘGOREK T. 2016. Ocena elementów składowych bilansu wodnego odwodnionego torfowiska [Assessment of components of the water balance of drained peatbog]. Rocznik Ochrona Środowiska. Nr 18 p. 519-530.

GrZYWNA A., TARKOWSKA-KUKURYK M., BOCHNIAK A., MarczuK A., JóźWIAKOWSKi K., Marzec M., MazUR A., OBroślaK R., NieŚCIORUK K., ZARAJCZYK J. 2015. Zastosowanie wskaźników chemicznych i biologicznych do oceny potencjału ekologicznego sztucznych cieków wodnych [Application of chemical and biological indicators for assessment of an ecological potential of artificial watercourses]. Przemysł Chemiczny. T. 94. Nr 11 p. 1954-1957.

HAaG D., KaEPEnJohann M. 2001. Landscape fate of nitrate fluxes and emissions in Central Europe. A critical review of concepts, data and models for transport and retention. Agriculture and Ecosystem Environment. Vol. 86 p. $1-21$.

Jarvie H.P., Withers P.J.A., Bowes M.J., PAlmer-Felgate E.J., Harper D.M., Wasiak K., Wasiak P., Hodgkinson R.A., Bates A., Stoate C., Neal M., Wickham H.D., HaRman S.A., ARMSTRONG L.K. 2010. Stream water phosphorus and nitrogen across a gradient in rural-agricultural land use intensity. Agriculture and Ecosystem Environment. Vol. 135 p. 238-252.

KACZOROWSKA Z. 1962. Opady w Polsce w przekroju wieloletnim [Precipitation of the Poland in long-term cycle]. Prace Geograficzne. Nr 33 p. 1-112.

KANCLERZ J. 2011. Wpływ jeziora Gorzuchowskiego na jakość wód rzeki Małej Wełny [The influence Gorzuchowskie Lake on the water quality Mała Wełna River]. Nauka, Przyroda, Technologia. Nr 5 p. 73-82.

KOC J., DUDA M., TUCHOLSKI S. 2008. Znaczenie zbiornika retencyjnego dla ochrony jeziora przed spływami fosforu ze zlewni rolniczej [Role of storage reservoir in protecting lake against phosphorus inflow from agricultural catchment]. Acta Scientiarum Polonorum. Formatio Circumiectus. Vol. 7 (1) p. 13-24.

KORNAŚ M., GrZEŚKOWIAK A. 2011. Wpływ użytkowania zlewni na kształtowanie jakości wody w zbiornikach wodnych zlewni rzeki Drawy [The impact of land use on water quality in water reservoirs of the Drawa River catchment]. Woda-Środowisko-Obszary Wiejskie. T. 11. Z. 1 p. 125-137.

MichalczyK Z., Wilgat T. 1998. Stosunki wodne Lubelszczyzny [Water relations of the Lublin region]. Lublin. UMCS pp. 167.

PIERZGALSKI E. 2008. Relacje między lasem i woda - przegląd problemów [The relationship between forest and water - a review of the problems]. Studia i Materiały Centrum Edukacji Przyrodniczo-Leśnej. R. 10. Z. 2 (18) p. 13-23.

Pierzgalski E., JaneK M., Kucharska K., TyszKa J., WRÓBEL M. 2007. Badania hydrologiczne w leśnych zlewniach sudeckich [Hydrological research in the Sudeten forest catchment]. Warszawa. IBL. ISBN 978-8387647681 pp. 84.

PoKŁADEK R., Nyc K. 2007. Możliwości gospodarowania wodą w małych zlewniach rolniczych [Possibility of water management in small agricultural catchments]. Zeszyty Problemowe Postępów Nauk Rolniczych. Z. 519 p. $259-268$.

Pulikowski K., Czyżyk F., Pawęska K., Strzelczyk M. 2011. Sezonowe zmiany wielkości ładunku azotu odpływającego z mikrozlewni użytkowanych rolniczo [Seasonal changes in the size of nitrogen load outflow from micro-catchments used for agricultural purposes]. Infrastruktura i Ekologia Terenów Wiejskich. Nr 10 p. 161-171.

Rozporządzanie Ministra Środowiska z 21 lipca 2016 roku w sprawie sposobu klasyfikacji stanu ekologicznego jednolitych części wód powierzchniowych i środowiskowych norm jakości dla substancji priorytetowych [Regulation Minister of the Environment of 21 July 2016 on the method of classification of ecological status of surface water bodies and environmental quality standards for priority substances]. Dz. U. 2016 poz. 1187.

SCOTt D.F., Sмiтн R.E. 1997. Preliminary empirical models to predict reduction in total and low flows resulting from afforestation. Water SA. Vol. 23. No. 2 p. 135140.

SZYMCZYK S. 2010. Influence of the type of soil dewatering and land use on the dynamics of concentrations and volume of nitrogen discharged from agricultural areas. Journal of Elementology. Vol. 15 (1) p. 189-211.

VAN DiJK A., KEENAN R. 2007. Planted forest and water perspective. Forest Ecological Management. Vol. 251 (1) p. 1-9.

WeILER M., MCDonNELl J.J. 2007. Conceptualizing lateral preferential flow and flow networks and simulating the effects on gauged and un gauged hill slopes. Water Resource. Vol. 43 (3) p. 1-13.

WheATER H., Evans E. 2009. Land use, water management and future flood risk. Land Use Policy. Vol. 26 p. 251264.

ŻelaZny M., Siwek J.P., Fidelus J., StańCZyk T., Siwek J., RutKowsKa A., KRUK P., Wolanin A., JELONKIEWICZ Ł. 2017. Wpływ wiatrołomu i degradacji drzewostanu na zróżnicowanie chemizmu wód $\mathrm{w}$ zlewni Potoku Kościeliskiego w obszarze Tatrzańskiego Parku Narodowego [Effect of wind damage to tree stands on spatial differences in water chemistry in the Kościeliski Stream catchment in the Tatra National Park]. Sylwan. T. 161. Z. 1 p. 27-33. 


\section{Antoni GRZYWNA}

\section{Zmiany ilości i jakości wody odpływającej ze zlewni rzeki Ochożanki}

\section{STRESZCZENIE}

Celem pracy jest ocena zmian ilości wody i napływających składników odżywczych. Badania przeprowadzono w hydrologicznym okresie pięcioletnim na Polesiu Zachodnim. W strukturze użytkowania zlewni Ochożanki o powierzchni 33,1 $\mathrm{km}^{2}$ dominują lasy stanowiące $81 \%$. W okresie badań wielkość opadów wynosiła 627 $\mathrm{mm}$ i była o $100 \mathrm{~mm}$ większa od średniej wieloletniej. Opad w półroczu letnim był prawie trzykrotnie wyższy niż w półroczu zimowym. Analiza danych wskazuje, że średni roczny odpływ jednostkowy wyniósł 3,0 $\mathrm{dm}^{3} \cdot \mathrm{s}^{-1} \cdot \mathrm{km}^{-2}$. Odpływ w półroczu zimowym był o $52 \%$ większy niż w półroczu letnim. Wody rzeki charakteryzują się zazwyczaj dobrym stanem chemicznym. W przypadku 30\% próbek przekroczone były wartości graniczne II klasy jakości wody stężenia azotu Kjeldahla $\left(>2 \mathrm{mg} \mathrm{N} \cdot \mathrm{dm}^{-3}\right)$ i fosforu ogólnego $\left(>0,4 \mathrm{mg} \mathrm{P} \cdot \mathrm{dm}^{-3}\right)$. Wskaźniki tlenowe charakteryzowały się wartościami średnimi i dużymi. Wiosną bardzo często były przekroczone wartości graniczne II klasy jakości. Wówczas wartości te wynosiły - dla ChZT $>20 \mathrm{mg} \mathrm{O}_{2} \cdot \mathrm{dm}^{-3} \mathrm{i}$ natlenienia $<5$ $\mathrm{mg} \mathrm{O}_{2} \cdot \mathrm{dm}^{-3}$. Ważną kwestią związaną $\mathrm{z}$ wartościami parametrów jest sezonowa zmienność ich stężenia w wodzie odpływającej ze zlewni. Maksymalne wartości parametrów chemicznych odnotowano w marcu, kiedy występują największe odpływy wody.

Słowa kluczowe: klasa jakości, odptyw wody, opady, zlewnia leśna 